\title{
PENERAPAN MODEL QUANTUM TEACHING UNTUK MENINGKATKAN VERBAL-LINGUISTIK SISWA PADA PEMBELAJARAN IPS
}

\author{
Roni Rodiyana \\ PGSD-Universitas Majalengka
}

\begin{abstract}
ABSTRAK
Berdasarkan latar belakang yang peneliti temukan di lapangan yaitu siswa belum mampu berinteraksi dengan menggunakan bahasa yang baik, dan belum mampu menyampaikan pemahamannya.Tujuan dalam penelitian ini adalah untuk mengetahui peningkatan verbal-linguistik siswa dengan menggunakan model quantum teaching pada pembelajaran IPS di kelas IV SDN Cikoneng IKecamatan Sukahaji Kabupaten Majalengka.Model penelitian yang digunakan dalam penelitian ini adalah penelitian tindakan kelas (PTK) dengan instrumen yang digunakan adalah tes, observasi, dan dokumentasi.Secara keseluruhan pelaksanaan tindakan kelas berjalan dengan lancar sesuai rencana yang telah disusun dan dilakukan disetiap siklusnya. Jumlah tindakan sebanyak empat kali, tiap tindakannya memperoleh hasil yang berbeda-beda, dapat diketahui melalui hasil pada siklus I tindakan 1 sebesar $61 \%$, pada tindakan 2 menjadi $72 \%$, dan pada siklus II tindakan 1 sebesar 83\%, pada tindakan 2 menjadi 95\%. Peneliti berharap guru dapat mengimplementasikan model ini dengan optimal supaya hasilnya maksimal.
\end{abstract}

Kata Kunci: Model Quantum Teaching, Verbal-linguistik. 


\title{
IMPLEMENTATION QUANTUM TEACHING MODEL FOR IMPROVING STUDENT IN LINGUISTICSVERBAL AT SOCIAL STUDIES
}

\author{
Roni Rodiyana \\ ronirodiyana@yahoo.com \\ education courses of primary school teachers \\ MajalengkaUniversity
}

\begin{abstract}
Based on the background that researchers found in the field that the student has not been able to interact with it using good language, and have not been able to convey understanding. The purpose of this research was to determine the increase in verbal linguistic student by using model of quantum teaching in social studies lesson in class IV SDN Cikoneng I district Sukahaji Majalengka. The research model used in this study is classroom action research (CAR) with the instruments used are tests, observation, and documentation. The overall implementation of the class action runs smoothly according to the plan that has been drawn up and carried out in every cycle. Number of action four times, each action get the results vary, it can be seen through the results of the first cycle of action 1 by $61 \%$, in the action 2 into $72 \%$, and the second cycle of action 1 by $83 \%$, in the action of 2 into $95 \%$. Researchers hope the teachers can implement this model with the optimum order for maximum results.
\end{abstract}

Keywords: Quantum Teaching Model, Linguistics Verbal

\section{A. Pendahuluan}

Pendidikan mempunyai peranan penting dalam kehidupan suatu bangsa, maju tidaknya suatu bangsa dipengaruhi oleh kualitas pendidikan bangsa itu sendiri. Kementrian Pendidikan Nasional tahun 2012 menetapkan Visi Pendidikan Indonesia yaitu terselenggaranya layanan prima pendidikan dan kebudayaan nasional untuk membentuk anak Indonesia yang cerdas dan berkarakter, sehingga bisa membentuk gambaran kondisi masa depan Indonesia yang diarahkan secara konsisten.

Visi diatas sejalan dengan Undang-undang Nomor 20 tahun 2003 pasal 3, tentang Sistem Pendidikan Nasional yang merumuskan Pendidikan Nasional berfungsi mengembangkan kemampuan untuk membentuk karakter dalam mencerdaskan kehidupan bangsa. Namun dalam kenyataan yang ada Tujuan Pendidikan Nasional belum terealisasi dengan maksimal, dimana masyarakat Indonesia sudah mulai kehilangan karakter bangsa yang santun, jujur, dan tutur bahasa yang baik.

Menurut Nursid Sumaatmadja (2008: 11) mengemukakan bahwa "Secara mendasar pelajaran Ilmu Pengetahuan Sosial (IPS) berkenaaan dengan kehidupan manusia yang melibatkan segala tingkah laku dan kebutuhannya". Adanya anggapan bahwa mata pelajaran IPS cenderung pada hafalan serta metode yang diterapkan guru 
cenderung pada aktifitas guru bukan pada aktifitas siswa, sehingga pembelajaran masih berpusat pada guru.

Sebagai seorang guru harus bisa menciptakan suasana pembelajaran yang bermakna, menyenangkan, kreatif, dinamis dan logis.Selain itu juga guru harus mempunyai komitmen untuk meningkatkan mutu pendidikan sehingga dapat tercapainya suatu tujuan pendidikan. Oleh karena itu, dalam menerapkan mata pelajaran Ilmu Pengetahuan Sosial (IPS), maka perlu upaya untuk melakukan perbaikan peningkatan kualitas pembelajaran Ilmu Pengetahuan Sosial (IPS), agar siswa menjadi lebih aktif untuk berinteraksi dan memahami konsep-konsep Ilmu Pengetahuan Sosial (IPS) dengan mudah. Sehingga hasil belajar siswa dapat memenuhi kriteria ketuntasan minimal yang telah ditetapkan dari pihak sekolah

Banyak hal yang bisa dilakukan oleh guru pada saat melakukan pembelajaran di kelas.Bisa dengan menggunakan media poster atau gambar dalam menyampaikan suatu informasi, dan bisa juga dalam permainan kecil tetapi yang menjurus pada pembelajaran.Dengan hal inilah anak bisa nyaman di dalam kelas untuk belajar. Bukan hanya dengan media saja yang di berikan pada anak tetapi cara atau model juga harus di perhatikan oleh guru sebelum melakukan pembelajaran. Salah satu model pembelajaran yang dapat membangkitkan anak dalam belajar yaitu dengan model quantum teaching. Pembelajaran quantum teaching dikembangkan oleh Bobby DePorter (2004: 125) yang beranggapan bahwa metode belajar ini sesuai dengan cara kerja otak manusia dan cara belajar manusia pada umumnya. Dengan model SuperCamp yang dikembangkan bersama kawan-kawannya, prinsip-prinsip dan model pembelajaran quantumteaching menentukan bentuknya.

Dalam model quantum teaching menyangkut khususnya keterampilan guru dalam merancang, mengembangkan, dan mengelola sistem pembelajaran sehingga guru mampu menciptakan suasana pembelajaran yang efektif, kreatif, dan efisien.Dengan demikian, model pembelajaran quantum teaching ini merupakan bentuk inovasi perubahan bermacam-macam interaksi yang ada di dalam dan di sekitar momen belajar. Menurut Ralph Waldo Emerson (hal: 50) menyatakan bahwa: "Senyaring apa pun katakata yang anda teriakan, saya tidak bisa mendengar sepatah katapun”. Jadi, langkah pertama mengajarkan kunci-kunci adalah dengan memberikan keteladanan.Kedua perkenalkanlah kunci-kunci melalui cerita dan perumpamaan, sedangkan yang ketiga terapkan kunci-kunci ke dalam kurikulum".

Bobby DePorter, (2004: 7) mengembangkan pembelajaran quantum teaching memiliki lima prinsip yaitu sebagai berikut: 1) Segalanya berbicara, maksudnya bahwa segalanya dari lingkungan kelas hingga bahasa tubuh guru dari gambar yang guru bagikan hingga rancangan pelajaran guru semuanya mengirim pesan tentang belajar. 2) Segalanya bertujuan, maksudnya semua yang terjadi dalam perubahan guru mempunyai tujuan untuk siswa semuanya. 3) Pengalaman sebelum pemberian nama, maksudnya otak kita berkembang pesat dengan adanya rangsangan kompleks yang akanmenggerakan rasa ingin tahu. Oleh karena itu, proses belajar paling baik terjadi ketika siswa telah mengalami informasi sebelum mereka memperoleh nama untuk apa yang mereka pelajari. 4) Akui setiap usaha, maksudnya belajar mengandung risiko, belajar berarti melangkah keluar dari kenyamanan. Pada saat siswa mengambil langkah 
ini mereka patut mendapat pengakuan atas kecakapan dan kepercayaan diri mereka. 5) Rayakan, maksudnya perayaan adalah sarapan pelajar juara, perayaan memberikan umpan balik mengenai kemajuan dan meningkatkan asosiasi emosi positif dengan belajar.

Dari uraian di atas disimpulkan bahwa model quantum teaching adalah pembelajaran yang harus disampaikan kepada anak dengan cara yang menyenangkan di dalam kelas, supaya anak tidak jenuh pada saat belajar di dalam kelas. Juga model ini dapat melatih siswa untuk berinteraksi dengan benar, baik siswa dengan guru, siswa dengan siswa, sehingga suasana anak di dalam kelas dapat menyenangkan untuk belajar. Dengan berinteraksi yang baik bisa menumbuhkan suasana nyaman di dalam kelas dan keadaan yang berbeda untuk menciptakan proses pembelajaran yang aktif, dan kreatif sehingga dalam verbal-linguistik anak bisa lebih baik.

Keadaan yang terjadi di lapangan yang bertempat di SD Negeri Cikoneng I Kecamatan Sukahaji Kabupaten Majalengka masih banyak anak dalam verballinguistiknya kurang, di antaranya kurang berinteraksi menggunakan bahasa yang baik, kurang dalam menyampaikan pemahamannya dengan benar, dan kurang dalam menghubungkan media dengan kata.Sekitar 50\% anak dalam verbal-linguistiknya yang terbilang baik di kelas IV SD Negeri Cikoneng I Kecamatan Sukahaji Kabupaten Majalengka.

Apabila ada anak yang tidak bisa berkomunikasi bahasa yang baik dengan guru maupun dengan teman yang lainnya, itu sangat berpengaruh pada kondisi anak. Apabila di biarkan pasti akan berdampak buruk untuk tahap berkembangnya anak. Bagi orang tua atau guru harus bisa meneliti setiap anak.Karena anak butuh perhatian dan bimbingan, baik itu dari orang tua sekalipun atau juga dari guru di sekolah. Sebagai seorang guru harus mampu menanamkan verbal-linguistik dari sejak dini, hal tersebut akan memudahkan anak sampai besar nanti aktif dalam berkomunikasi menggunakan bahasa yang baik. Menurut Slatin (2005: 13) menyatakan bahwa:

"Kecerdasan verbal-linguistik adalah kemampuan untuk berkomunikasi menggunakan bahasa, termasuk bahasa ibu dan bahasa asing, untuk mengekspresikan apa yang ada di dalam pikiran dan memahami orang lain".

Sedangkan menurut McKenzie (2005: 13) menyatakan bahwa:"Kecerdasan Linguistik disebut juga kecerdasan verbal karena mencakup kemampuan untuk mengekspresikan diri secara lisan dan tertulis, serta kemampuan untuk menguasai bahasa asing". Berdasarkan pendapat di atas menunjukan bahwa, anak yang sudah memahami verbal-linguistik yang baik, tingkat kecerdasannya lebih meluas dari pada anak yang lain. Hal ini di dasari dari pengalaman mengajar dan hasil observasi di kelas IV SD Negeri Cikoneng I Kecamatan Sukahaji Kabupaten Majalengka.Menurut Thais dan Bromley (2005: 26) mengemukakan Indikator Kecerdasan Verbal-Linguistik, yaitu sebagai berikut: 1) Mendengarkan, yaitu mampu mendengarkan dengan benar dan tepat merupakan bagian yang penting dalam belajar dan berkomunikasi. 2) Berbicara, merupakan salah satu alat untuk komunikasi yang paling efektif. 3) Membaca, yaitu pengembangan minat yang baik harus dimulai sejak dini pada anak. 4) Menulis, merupakan kemampuan yang sangat berkaitan dengan menggambar pada anak. 5) Perlu adanya suatu upaya untuk melakukan perbaikan verbal-linguistik dan peningkatan kualitas belajar Ilmu Pengetahuan Sosial (IPS), agar siswa menjadi lebih aktif dan 
memahami konsep-konsep Ilmu Pengetahuan Sosial (IPS) dengan mudah, sehingga hasil belajar siswa dapat memenuhi kriteria ketuntasan minimal KKM 70 yang telah ditetapkan oleh sekolah.

Khususnya pada siswa kelas IV SD Negeri Cikoneng I Kecamatan Sukahaji Kabupaten Majalengka dalam pembelajaran Ilmu Pengetahuan Sosial (IPS), pada materi Masalah-masalah Sosial masih banyak yang belum begitu paham untuk menyampaikan hasil pemahamannya dengan benar.Baik masalah di keluarga, sekolah, juga di lingkungan sekitar.Hal tersebut merupakan salah satu penyebab terjadinya masalah pada anak yang ada di kelas IV SD Negeri Cikoneng I Kecamatan Sukahaji Kabupaten Majalengka.Oleh karena itu, perlu adanya upaya yang dilakukan guru untuk mengatasi masalah tersebut agar tujuan pembelajaran yang diharapkan bisa tercapai. Salah satu cara yang dapat dilakukan untuk meningkatkan pembelajaran dalam verballinguistik siswa adalah dengan melalui model quantum teaching. Berdasarkan uraian dari latar belakang masalah tersbeut maka tujuan dari penelitian ini adalah: 1) Untuk mengetahui penerapan model quantum teaching pada pembelajaran Ilmu Pengetahuan Sosial (IPS) di kelas IV SD Negeri Cikoneng I Kecamatan Sukahaji Kabupaten Majalengka. 2) Untuk mengetahui verbal-linguistik pada pembelajaran Ilmu Pengetahuan Sosial (IPS) di kelas IV SD Negeri Cikoneng I Kecamatan Sukahaji Kabupaten Majalengka. 3) Untuk mengetahui hasil dari model quantum teaching dapat meningkatkan verbal-linguistik siswa pada pembelajaran Ilmu Pengetahuan Sosial (IPS) di kelas IV SD Negeri Cikoneng I Kecamatan Sukahaji Kabupaten Majalengka.

\section{B. Metode Penelitian}

Waktu pelaksanaan penelitian ini adalah pada semester II bulan Mei tahun pelajaran 2014/2015.Penelitian ini dilaksanakan dalam 4 pertemuan. Dalam siklus I dilakukan pada tanggal 25-26 Agustus 2015 sebesar 2 tindakan, sedangkan pada siklus II dilakukan pada tanggal 28-29 Agustus 2015 dalam 2 pertemuan 2 tindakan. Penelitian tindakan kelas ini pada siswa kelas IV tahun pelajaran 2014/2015 dengan jumlah siswa 18 orang, yakni 13 orang siswa laki-laki dan 5 orang siswa perempuan.

Teknik pengumpulan data yang digunakan dalam penelitian ini adalah teknik pengukuran dengan alat pengumpul data berupa tes hasil belajar dari non tes berupa wawancara, pengamatan, dan dokumentasi daftar hasil belajar siswa serta lembar aktivitas siswa terhadap pembelajaran IPS yang dilakukan.Penelitian Tindakan Kelas (PTK) pada dasarnya sudah menjadi sebuah kebutuhan bagi guru untuk meningkatkan profesionalnya. Penelitian Tindakan Kelas (PTK) ini sangat cocok dilakukan oleh guru karena akan merangsang guru untuk lebih peka terhadap dinamika pembelajaran di kelas. Guru juga dapat mengetahui bagaimana perkembangan proses pembelajaran siswa melalui suatu kajian yang lebih mendalam terhadap apa yang terjadi di kelas dan mengikuti perkembangan ilmu pendidikan yang belakangan sudah sangat maju

Penelitian Tindakan Kelas (PTK) memberikan formulasi baru dalam proses pembelajaran. Adapun manfaat yang dapat dilihat dan dikaji dalam beberapa komponen pendidikan dan pembelajaran mencakup inovasi pembelajaran, pengembangan kurikulum dan tingkat regional atau nasional serta peningkatan profesionalisme pembelajaran.Ada beberapa ahli yang mengemukakan model penelitian tindakan 
dengan bagan yang berbeda, namun secara garis besar terdapat empat tahapan yang lazim dilalui, yaitu (1) perencanaan, (2) tindakan, (3) observasi, dan (4) refleksi.

Indikator keberhasilan dalam penelitian ini apabila 95\% dari jumlah 18 anak didik kriteria ketuntasan yang telah ditentukan oleh penulis. Anak yang telah memperoleh angka 3 berarti telah memenuhi kriteria tuntas semua, sedangkan anak yang mampu mencapai kriteria dengan nilai 2 berarti anak telah memenuhi kriteria tuntas, kemudian bagi anak yang memperoleh nilai 1 berarti anak tersebut belum mencapai kriteria tuntas dan aspek indikator yang diharapkan belum dapat dicapai oleh anak. Angka keberhasilan 95\% itu didapat dari anak yang memperoleh nilai 2 dan 3

\section{Hasil Penelitian}

Pada siswa kelas IV SD Negeri Cikoneng I Kecamatan Sukahaji Kabupaten Majalengka, masih ada siswa yang kurang dalam menyampaikan pemahamannya, kurang berinteraksi menggunakan bahasa yang baik, dan kurang dalam menghubungkan media dengan kata. Hal tersebut dikarenakan guru sebelumnya dalam menyampaikan pembelajaran IPS di kelas hanya dengan menggunakan metode ceramah, sehingga anak merasa bosan karena siswa tidak ikut aktif pada saat proses belajar berlangsung. Tentang masalah tersebut, maka saya meneliti di SD tersebut. Setelah dilakukan penelitian yang menggunakan model quantumteaching hasil dari meningkatkan verbal-linguistik menjadi sangat lebihbaik dan siswa ikut aktif saat proses belajar. Saya menggunakan 2 siklus dalam 4 pertemuan.Kondisi awal hanya 50\% anak yang verbal-linguistiknya baik, tetapi setelah dilakukan tindakan siklus I sampai siklus II verbal-linguistik semua ßnak meningkat.

Meningkatkan verbal-linguistik melalui model quantum teaching yang menggunakan gambar pada siswa kelas IV SD Negeri Cikoneng I. Berdasarkan nilai perkembangan anak didik sebelum di berikan tindakan, diketahui verbal-linguistik anak sangat rendah, tingkat perkembangan hanya mencapai 50\%, melihat kondisi yang demikian maka peneliti memberi model pembelajaran yang berbeda dengan menerapkan model quantum teaching yang menggunakan gambar masalah-masalah sosial maka terjadi peningkatan secara bertahap dari siklus I pertemuan 1 terjadi peningkatan sekitar $11 \%$, yaitu sekitar 11 anak, kemudian dilakukan penelitian ulang pada pertemuan 2 siklus I terjadi peningkatan sekitar 12\%, yaitu sekitar 11 anak. Sedangkan pada Siklus II pertemuan 1 terjadi peningkatan sekitar 11\%, yaitu sekitar 15 anak, kemudian dilakukan penelitian lagi untuk memperoleh hasil yang maksimal pada pertemuan 2 siklus II terjadi peningkatan sekitar 12\%, yaitu sekitar 18 anak.

Sebagaimana kita ketahui bahwa indikator verbal-linguistik meliputi 4 area utama, yaitu mendengarkan, berbicara, membaca, dan menulis. Berikut ini persentase peningkatan verbal-linguistik yang dilakukan pada siklus I dan II, dan uraian bagaimana menciptakan lingkungan yang dapat memperkaya verbal-linguistik siswa adalah: Mendengarkan berdasarkan data diatas pada siklus I, dapat diketahui bahwa anak didik yang mengerti beberapa perintah secara sederhana ada 55\%, mengulang kalimat yang lebih kompleks ada $61 \%$, dapat menyebutkan sebanyak-banyaknya masalah sosial ada $66 \%$, sedangkan pada siklus II mengalami peningkatan sebagai berikut: dapat mengerti 
beberapa perintah secara sederhana 95\%, dapat mengulang kalimat yang lebih kompleks $88 \%$, dapat menyebutkan sebanyak-banyaknya masalah sosial ada $88 \%$.

1. Mendengarkan

Mampu mendengarkan dengan benar dan tepat merupakan bagian yang penting dalam belajar dan berkomunikasi.Hal ini sangat penting dalam tahap-tahap pertama dari belajar membaca.Untuk meningkatkan kemampuan mendengarkan pada anak, maka yang dapat dilakukan oleh orang tua dan pendidik adalah menjadi model yang baik bagi anak, berkomunikasi yang jelas kepada anak, dan memberikan penguasaan pengetahuan dan aktivitas yang berkenaan dengan kegiatan mendengarkan itu sendiri. Pada siklus I dapat menjawab mengerti beberapa perintah secara sederhana 55\%, mengulang kalimat yang lebih kompleks 61\%, sedangkan pada siklus II hasilnya akan lebih meningkat.

2. Berbicara

Pada siklus I dapat menjawab pertanyaan yang lebih kompleks ada 66\%, dapat menceritakan kejadian sebab akibat $72 \%$, dapat menyebutkan sebanyak-banyaknya masalah sosial yang sudah terjadi 66\%, sedangkan pada siklus II mengalami peningkatan sebagai berikut: dapat menjawab pertanyaan yang lebih kompleks 95\%, dapat menceritakan kejadian sebab akibat 95\%, dapat menyebutkan sebanyakbanyaknya masalah sosial yang sudah terjadi $88 \%$. Bicara merupakan salah satu alat berkomunikasi yang paling efektif.

3. Membaca

Pada siklus I dapat menghubungkan gambar masalah sosial dengan kata ada $55 \%$, dan yang mengalami peningkatan membaca materi dengan jelas $72 \%$.Sedangkan pada siklus II hasil dari menghubungkan gambar masalah sosial dengan kata ada 95\%, dan yang mengalami peningkatan membaca materi dengan jelas ada 95\%.Hal ini meningkat lebih berhasil lagi pada siklus II.Pengembangan minat dan kebiasaan membaca yang baik harus dimulai sedini mungkin pada anak-anak.Orang tua, terutama ibu dan guru mempunyai peranan yang sangat penting dalam menentukan usaha-usaha pengembangan minat dan kemampuan membaca.

4. Menulis

Pada siklus I dapat memahami materi yang sudah di sampaikan ada 61\%, dan dapat menuliskan pemahaman masing-masing tentang masalah-masalah sosial ada $61 \%$, sedangkan pada siklus II mengalami peningkatan yaitu dapat memahami materi yang sudah di sampaikan ada 95\%, dan dapat menuliskan pemahaman masing-masing tentang masalah-masalah sosial ada $95 \%$

Selain anak menggambarkan sesuatu yang ada dalam pikirannya ke dalam kertas, anak juga perlu menceritakan makna dari gambar yang dibuatnya.Disinilah orang tua atau pendidik memainkan peran yang penting dalam mengenalkan anak pada kekuatan komunikasi antara gambar yang dibuatnya dengan kata-kata yang dapat dimunculkan anak. Jika pendidik dapat membuat pengalaman menggambar ini menjadi menantang, maka anak akan menguasai sistem simbol yang beragam lainnya. Hasil selengkapnya dapat disajikan pada tabel berikut: 


\section{Tabel 1}

\section{Perbandingan Nilai Siklus I Sampai Siklus II Kelas IV SD Cikoneng I Kecamatan Sukahaji Kabupaten Majalengka}

\begin{tabular}{|c|l|c|c|}
\hline No. & \multicolumn{1}{|c|}{ Siklus } & Ketuntasan & Keterangan \\
\hline 1 & Tindakan 1 Siklus I & $61 \%$ & Belum berhasil \\
\hline 2 & Tindakan 2 Siklus I & $72 \%$ & Cukup berhasil \\
\hline 3 & Tindakan 1 Siklus II & $83 \%$ & Sudah berhasil \\
\hline 4 & Tindakan 2 Siklus II & $95 \%$ & Sangat berhasil \\
\hline
\end{tabular}

Berdasarkan tabel di atas diketahui ada peningkatan verbal-linguistik pada anak dilihat dari kondisi awal: 50\%, siklus I pertemuan 1: $61 \%$, pertemuan 2 menjadi $72 \%$, sadangkan pada siklus II pertemuan $183 \%$, dan pada pertemuan 2 menjadi $95 \%$, sehingga prosentase kenaikan dari prasiklus ( kondisi awal) ke siklus I adalah 22\%, dan proses kenaikan dari siklus I ke siklus II adalah 23\%. Menurut pandangan Hurlock (2001: 176) mengemukakan bahwa: "Verbal-linguistik adalah sarana komunikasi dengan menyimbolkan pikiran dan perasaan untuk menyampaikan makna kepada orang lain". Tetapi menurut Syamsu Yusuf (2007: 118) mengatakan bahwa: "Verballinguistik adalah sarana berkomunikasi dengan orang lain. Dalam pengertian ini tercakup semua cara untuk berkomunikasi, dimana pikiran dan perasaan dinyatakan dalam bentuk lambang atau simbol untuk mengungkapkan suatu pengertian".

Berdasarkan uraian di atas Thais mengemukakan bahwa anak dapat memahami dan mengingat suatu informasi jika mereka mendapat kesempatan untuk membicarakannya, menuliskannya,menggambarkannya, dan memanipulasinya. Anak belajar membaca dan menyimak jika mereka mendapat kesempatan untuk mengekspresikan pemahaman mereka dengan membicarakannya untuk diri mereka sendiri maupun di tujukan pada orang lain.

Belajar jika ada diskusi antara guru dan anak, anak dan anak, anak dan media, serta anak dan lingkungannya.Verbal-linguistik dan belajar tidak dapat di pisahkan.Kemampuan meningkatkan verbal-linguistik secara efektif sangat berperan penting terhadap kemampuan belajar anak.Maka dari itu pembelajaran dengan metode bercerita dengan bantuan madia audio visual sangat bermanfaat guna meningkatkan perkembangan verbal-linguistik anak, anak tidak merasa jenuh dan sangat antusias dalam mengikuti pembelajaran. Hasil penelitian tindakan kelas yang telah dilaksanakan selama II siklus dalam meningkatkan verbal-linguistik materi masalah-masalah sosial pada siswa kelas IV SD Negeri Cikoneng I melalui model pembelajaran quantum teaching dapat disimpulkan sebagai berikut:

Performansi guru dalam menerapkan model pembelajaran quantumteaching sudah sangat lebih baik.Performansi guru pada tindakan 1siklus I memperoleh nilai 15 
(Kurang), pada tindakan 2 siklus I memperoleh nilai 20 (Baik), sedangkan pada tindakan 1 siklus II memperoleh nilai 21 (Sangat Baik), dan pada tindakan 2 siklus II memperoleh nilai 24 (Sangat Baik).Sehingga nilai performansi guru mengalami peningkatan yang sangat baik.

Pada siswa kelas IV SD Negeri Cikoneng I Kecamatan Sukahaji Kabupaten Majalengka, masih ada siswa yang kurang dalam menyampaikan pemahamannya, kurang berinteraksi menggunakan bahasa yang baik, dan kurang dalam menghubungkan media dengan kata. Hal tersebut dikarenakan guru sebelumnya dalam menyampaikan pembelajaran IPS di kelas hanya dengan menggunakan metode ceramah, sehingga anak merasa bosan karena siswa tidak ikut aktif pada saat proses belajar berlangsung. Tentang masalah tersebut, maka saya meneliti di SD tersebut. Setelah dilakukan penelitian yang

menggunakan model quantum teaching hasil dari meningkatkan verballinguistik menjadi sangat lebih baik dan siswa ikut aktif saat proses belajar. Saya menggunakan 2 siklus dalam 4 pertemuan.Kondisi awal hanya 50\% anak yang verballinguistiknya baik, tetapi setelah dilakukan tindakan siklus I sampai siklus II verballinguistik semua anak meningkat.

Pembelajaran model quantum teaching dapat meningkatkan verbal-linguistik siswa. Hal ini ditandai sangat berpengaruh baik pada peserta didik di bantu dengan menggunakan gambar dan bernyanyi ketika kegiatan dilakukan membuat anak menyenangkan ikut belajar. Anak bisa percaya diri menyampaikan pemahamannya, berinteraksi dengan menggunakan bahasa yang baik, da bisa menghubungkan media dengan gambar. Untuk hasil pada siklus I pertemuan ke 1 sebesar $61 \%$, pertemuan ke 2 menjadi $72 \%$, sedangkan pada siklus II pertemuan ke 1 sebesar $83 \%$, pada pertemuan ke 2 menjadi 95\%. Tiap siklus dan tindakan mempunyai hasil yang sangat meningkat dari kondisi awal sebesar 50\% menjadi 95\% verbal-linguistik anak tercapai dengan baik

\section{E. Pembahasan}

\section{Tindakan 1 Siklus I}

Di dalam perencanaan peneliti melakukan kegiatan kerja kelompok yang menggunakan media gambar masalah sosial.Tetapi pada saat siswa melakukan kegiatan kerja kelompok terlihat 1 atau 2 orang yang tidak aktif dalam kelompoknya masingmasing. Setelah selesai kegiatan berkelompok, kemudian guru sedikit mengulas apa yang sudah dikerjakan oleh semua siswa, dengan memberikan pertanyaan sederhana, seperti: "apakah sekarang di sekitar tempat tinggalmu ada masalah sosial? Kalau ada bagaimana kejadian tersebut bisa terjadi?".

Pada kegiatan ini yang menjawab adalah reza dan muhammad hikam yang begitu antusias dalam menjawab pertanyaan dari guru dan yang lainnya masih belum merespon pertanyaan yang diajukan oleh guru. Tetapi akan di lanjutkan pada pertemuan kedua supaya anak-anak bisa lebih mengerti. Pada pertemuan 1 siklus I masih dijumpai beberapa anak yang belum ada peningkatan, ada yang tidak berani menyampaikan pemahamannya, ada yang hanya diam saja, dan ada yang tidak aktif saat belajar atau berkelompok, sehingga perlu di motivasi kembali untuk dapat meningkatkan verbal- 
linguistiknya. Namun masih dibutuhkan tindakan lagi pada pertemuan 2 siklus I supaya mencapai indikator keberhasilan

2. Tindakan 2 Siklus I

Berdasarkan hasil refleksi pada tindakan 1 diketahui bahwa pemahaman siswa tentang masalah sosial belum maksimal.Media yang digunakan pada pertemuan kedua kali ini adalah gambar masalah sosial tentang tindak kejahatan, perilaku disiplin dan tidak disiplin. Guru memberikan arahan supaya gambar yang di pegang oleh masingmasing siswa harus diamati bagaimana masalah gambar tersebut dan apa sebab akibatnya lalu di tuliskan di papan tulis kemudian dibacakan. Masih banyak anak yang malu untuk menyampaikan pemahamannya secara langsung di dalam kelas.

3. Tindakan 1 Siklus II

Berdasarkan hasil refleksi pada siklus I diketahui bahwa pemahaman siswa tentang masalah sosial belum maksimal tetapi hasilnya sudah cukup baik.Media yang digunakan adalah gambar masalah sosial tentang pembodohan, kemiskinan dan pengangguran.Pada tindakan 1 siklus II peneliti mengamati perkembangan verballinguistik saat semua anak antusias menjawab, dan mengemukakan pendapat dari gambar dengan yang di pegang oleh semua siswa.Sehingga membuat anak menyenangkan aktif mengikuti kegiatan belajar, dan terlihat lebih semangat pada tindakan 1 siklus II ini. Seperti halnya dengan muhammad pandu dan syahda dengan penuh semangat berkata: "ibu, saya sering lihat di televisi banyak anak kecil mengamen dan mereka hanya tinggal di kolong jembatan bahkan mungkin tidak sekolah, begitu juga dengan aji, muhammad farhan, dan aulia juga sangat aktif bertanya". Meskipun masih ada beberapa anak yang terlihat diam. Pada tindakan 1 siklus II ini guru menekankan pada kebiasaan anak untuk terbiasa berinteraksi dengan baik menggunakan bahasa, menghubungkan media dengan kata, di mana anak bisa tahu sebab-akibat dari suatu kejadian sehingga anak bisa menyampaikan pemahaman yang sudah di sampaikan oleh guru. Pada pelaksanaan tindakan 1 siklus II ini guru sudah mulai terampil untuk dapat menarik perhatian anak agar menyenangkan belajar di dalam kelas.Hanya 2 orang yang masih saja kurang ikut aktif saat pembelajaran, tetapi sudah hampir semuanya anak perlahan-lahan dapat percaya diri untuk menyampaikan pemahamannya, dan bisa berinteraksi menggunakan bahasa dengan baik dari pada kegiatan sebelumnya.

Pada pertemuan 1 siklus II, guru mengingatkan kembali apa yang menyebabkan anak malas belajar dan akan mengakibatkan hal-hal yang tidak sepatutnya anak lakukan. Dari anak yang tidak bersekolah mungkin ada beberapa sebab, ada yang malas untuk sekolah, tidak ada biaya karena miskin, sehingga anak di suruh bekerja untuk mendapatkan uang memenuhi kehidupan sehari-hari.Guru juga menanyakan kepada peserta didik "apakah kalian mau untuk tidak sekolah?Jawaban yang kompak membalas tidak mau bu".

Guru menjelaskan kembali kalau anak yang malas dan tidak sekolah akan engakibatkan sampai besar nanti akan bodoh, tidak mempunyai pekerjaan tetapi akan menjadi pengangguran. Anak-anak begitu antusias mendengarkan apa yang guru sampaikan, setelah guru menjelaskan hal tersebut sebagian anak yang terus bertanya. Tetapi ada assyfa, intan, fazar, yang belum juga memahami pembelajaran dengan apa yang guru 
tanyakan pada mereka. Untuk selanjutnya maka guru memberi arahan terus menerus dan memberi bimbingan sampai anak tersebut bisa memahami sebab-akibat dari materi pada tindakan 1 siklus II ini supaya mereka mengerti dan bisa menyampaikan pendapat sesuai yang mereka pahami.

4. Tindakan 2 Siklus II

Berdasarkan hasil refleksi pada siklus I dan tindakan 1 pada siklus II diketahui bahwa pemahaman siswa tentang masalah sosial sudah mencapai nilai maksimal lulus dari KKM, tetapi peneliti ingin melakukan penelitian lagi supaya siswa memperoleh hasil yang sangat lebih baik lagi dengan guru memberikan tes soal lembar kerja siswa (LKS). Deskripsi data hasil implementasi tentang kemampuan anak dalam mengembangkan verbal-linguistik pada kegiatan pembelajaran dengan menggunakan gambar yang saling tukar adalah sebagai berikut: Dari 18 orang siswa yang mengikuti kegiatan tersebut di atas sudah melaksanakannya dengan sangat baik dan menyenangkan. Ada sekitar 95\% yaitu sebanyak 18 anak, dengan demikian hasil pelaksanaan tindakan kelas pada siklus II sudah sangat lebih baik dari pada siklus I

Pada siklus II ini guru sudah melaksanakan dengan baik dalam menyusun perencanaan, pelaksanaan, dan mengevaluasi dengan baik kegiatan pembelajaran. Keberhasilan anak adalah keberhasilan guru juga, dimana anak dan guru bisa terus lebih dekat apa yang menjadi kekurangan, kelebihan, dan kekurangan anak yang harus di perbaiki agar anak tersebut bisa memperbaikinya dengan gurunya yang terus mendekatinya dengan baik. Tidak ada anak yang selamanya memiliki kekurangan pasti sedikit demi sedikit kekurangan itu bisa diperbaiki dengan benar. Guru adalah contoh untuk anak apa yang guru sampaikan pasti anak akan mengingatnya, dan hal itulah yang sudah peneliti usahakan agar anak bisa merubah dirinya menjadi lebih baik. Berdasarkan pelaksanaan kegiatan yang dilaksanakan pada siklus II ini, bahwa kemampuan anak dalam meningkatkan verbal-linguistiknya sudah meningkat sesuai dengan yang diharapkan

\section{F. Bahan Rujukan}

Allen, Carole. (2004). Teaching and Learning Through Multiple Intelligences. Needham Heights, MA: Allyn and Bacon.

Amstrong, Thomas. (2009). Multiple Intelligences in the Classroom.3Edition. USA: ASCD.

Baum, et al. (2005).Multiple Intelligences in the Classroom: A Teacher's Toolkit. New York: Teachers College Press.

Belen, et al. (2007).Teori belajar IPS. Yogyakarta: Ar-Ruz Media.

Binet,HumanIntelligences.(2009). http:// www.indiana.edu/\%7Eintell/binet.shtml.

Connel, J. Diana. (2005). Brain Based Strategis to Reach Every Learner: Surveys, Questionnaires, andCheckliststhatHelpYouIdentifyStudents'Strengths- Plus Engaging Brain-Based Lessons andActivities, USA: Scholastic Inc. 
DePorter, Bobby. (2004). Quantum Bissines Achieving Success Through Quantumand Quantum Learning Unleashing the Genius in You.New York: Dell Publishing.

Fleetham, Mike. (2006). Multiple Intelligences in Practice: Enhancing Selfesteem and Learning in the Classroom. Great Britain: MPG Books Ltd,Bodmin, Cornwall.

Fritz, Walter. (2010). Intellegent Systems.[Online]. Tersedia: (http://intelligentsystem.com.ar/intsyst.htm).

Gardner, Howard. (2011). Frames of Mind. New York: Basic Books Inc.

Istiantiet, et al. (2007).Metodologi Penelitian Kualitatif. Bandung: Remaja Rosdakarya.

Jean, Piaget. (2002). The Psychology of Intelligence, Translated by Piercy M., and Berlyne D.E.New York: Routledge.

Kemmis dan Mc Taggart.(2001). Penelitian Tindakan Kelas.Jakarta: PT Bumi Angkasa.

Musfiroh. (2008). Pengembangan Kecerdasan Jamak, Jakarta: Universitas Terbuka.

McKenzie, Walter. (2005). Multiple Intelligences and Intructional Technology. Washington DC: International Society for Technology in Education.

Sanjaya.(2009). Penilaian Hasil Proses Belajar Mangajar. Bandung: PT Remaja Rosdakarya.

Suharsimi, Arikunto. (2010). Prosedur Penelitian. Jakarta: Gramedia.

Suryabrata, Sumadi .(2006).PsikologiPendidikan.Bandung: PT Remaja Rosdakarya.

Sugiyono.(2013). Statistika untuk Penelitian. Bandung: CV Alfabeta.

Thais dan Bromley.(2011). Indikator Verbal-linguistik. New York: Basic Books Inc.

Yaumi, muhammad. (2012). Ciri-ciri Anak Memiliki Verbal-linguistik. New York: Basic Books Inc. 